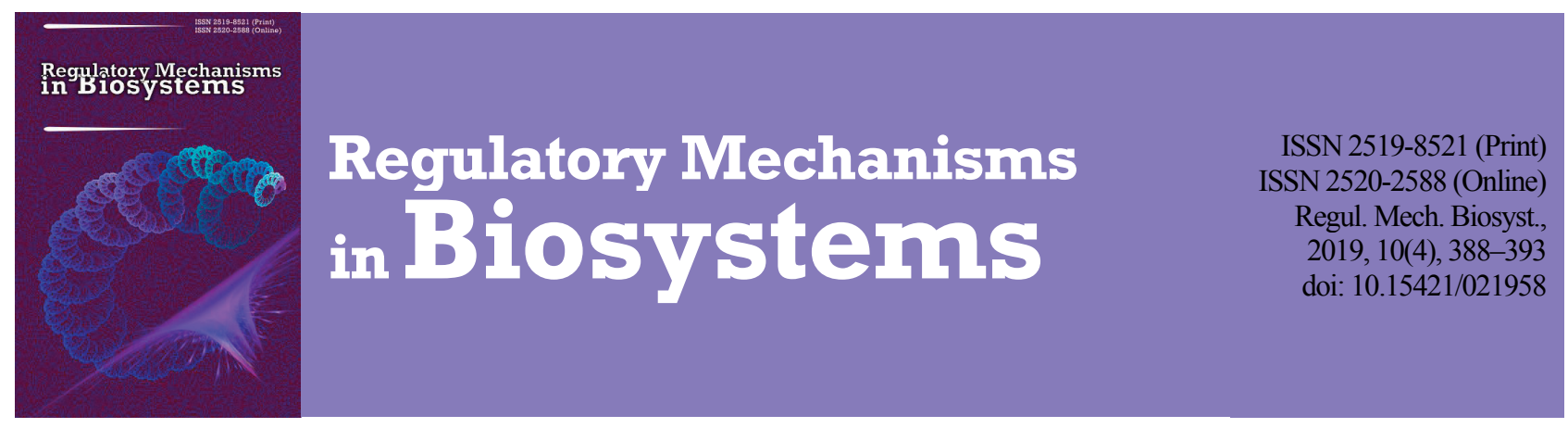

\title{
Evaluation of genetic diversity and relationships among eight Russian and Ukrainian cattle breeds based on microsatellite markers
}

\author{
E. A. Snegin*, A. S. Kramarenko**, E. A. Snegina*, S. S. Kramarenko** \\ *Belgorod National Research University, Belgorod, Russia \\ **Mykolayiv National Agrarian University, Mykolayiv, Ukraine
}

Article info

Received 14.09.2019

Received in revised form 18.10.2019

Accepted 20.10.2019

Belgorod National Research University, Pobedy st., 85 Belgorod, 308015, Russia Tel.: +7-903-642-16-13. E-mail:snegin@bsu.edu.ru

Mykolayiv National Agrarian University, Georgiy Gongadze st., 9, Mykolayiv, 54020, Ukraine. Tel.: +38-050-991-53-14. E-mail:

kssnail0108@gmail.com

\begin{abstract}
Snegin, E. A., Kramarenko, A. S., Snegina, E. A., \& Kramarenko, S. S. (2019). Evaluation of genetic diversity and relationships among eight Russian and Ukrainian cattle breeds based on microsatellite markers. Regulatory Mechanisms in Biosystems, 10(4), 388-393. doi:10.15421/021958
\end{abstract}

In recent years, special attention has been paid both to the preservation of the genetic diversity of cattle breeds in the Russian Federation and Ukraine, and to the evaluation of the breeds' 'purity', especially in relation to undesirable recessive lethal mutations. The main goal of our work was to assess the genetic diversity of the main cattle breeds bred in the Russian Federation and Ukraine using microsatellite DNA loci, as well as to evaluate the phylogenetic relationships between them. An analysis of molecular genetic diversity was carried out in different cattle breeds represented both in the Russian Federation and Ukraine. A total of 752 individuals, which belonged to eight breeds of the dairy and meat productivity directions were studied. Ten microsatellite loci recommended by ISAG-FAO and arranged in one multiplex panel (ETH3, INRA023, TGLA227, BM1818, TGLA122, SPS115, TGLA53, BM2113, BM1824 and ETH10) were used as DNA markers. Some alleles were found with a very high frequency in most of the studied cattle breeds and, thus, they can be considered as species-specific for the species Bos taurus as a whole. These were alleles 262 and $266 \mathrm{bp}$ (for BM1818), 180 and 188 bp (for BM1824), 125-127 and 133-135 bp (for BM2113), 217-219 bp (for ETH10), 248 and 252 bp (for SPS115). All breeds included in the analysis are characterized by a very high genetic uniqueness based on microsatellite loci; the accuracy of assigning the studied individuals to their own population varied within the range of $95-100 \%$. In general, all breeds studied are grouped into two clusters. Cluster No. 1 contains genetic groups originating from Holstein, and cluster No. 2 contains the remaining breeds. Three breeds (Ayrshire, Simmental and Russian Red Pied) are characterized by very low estimates of the effective population size (less than 50 animals), which may lead to the loss of their genetic uniqueness in the future. In the study of eight dairy and meat cattle breeds that are bred in the Russian Federation and Ukraine, we found that the breeds differ significantly in the genetic polymorphism indicators over ten MS-DNA loci used. Moreover, the level of allelic diversity for the studied breeds was determined, primarily, by the presence and number of rare (and/or "private") alleles. This may be due to the manifestation of different mechanisms of the formation and maintenance of genetic polymorphism in breeds, based on productivity direction.

Keywords: microsatellite DNA loci; genetic diversity; dairy and meat cattle breeds.

\section{Introduction}

The dairy cattle livestock bred today on the farms of the Russian Federation is classified as 19 breeds and 23 intrabreed types. The Russian Black Pied is most widespread cattle breed (which was bred by crossing the Dutch Black-and-White breed with local ones), in addition, the relative proportion of the Simmental, Russian Red Pied, and Red Steppe breeds is high also (Dunin et al., 2013). On the other hand, at present many farms of the Russian Federation contain Holstein cattle (Black Pied and Red Pied dairy cows). In Ukraine, about $75 \%$ of dairy cattle livestock is represented by two breeds, the Ukrainian Black Pied and the Ukrainian Red Pied dairy breed. They were also bred as a result of crossbreeding of local breeds with Holstein, and in the second case, representatives of the local Simmental and imported breeding material of the Ayrshire (Finland), Montbeliard (France) and Holstein (USA, Canada) breeds (Gladiy et al., 2015). It is shown that the Holstein has a great influence on the genetic progress of the Russian Black Pied dairy cows. Recessive lethal mutations BLAD (bovine leukocyte adhesion deficiency), CVM (complex vertebral malformation), DUMPS (deficiency of uridine monophosphate synthase), BY (brachispina syndrome) were brought in with Holstein breeders (Prokhorenko, 2013). In addition, 17 haplotypes that negatively affect the reproductive traits of livestock have already been identified (Labinov \& Prokhorenko, 2015). Thus, among dairy cattle breeds, the allele pool of the Russian Black Pied cattle, which has been formed for centuries on the basis of local cattle and adapted to various natural and climatic zones of the country, is threatened with extinction due to intensive crossbreeding with the Holstein breed.

Since indigenous domestic breeds make a significant contribution to the genetic diversity of domesticated species, a reduction in their numbers and the genetic pollution of the native allele pool can be one of the main reasons for the decreasing biodiversity of domesticated species (Zinovieva et al., 2015).

Therefore, in recent years, special attention has been paid both to the preservation of the genetic diversity of cattle breeds in the Russian Federation and Ukraine, and to the evaluation of the breeds' 'purity', especially in relation to undesirable recessive lethal mutations. The most useful tool for conducting such studies are microsatellite DNA(MS-DNA) loci. According to the INRA database (French National Institute for Agricultural Research; institut.inra.fr), already in the early 2010s, more than 2,400 MSDNA loci were identified on all 30 pairs of cattle chromosomes, of which 2,244 were already mapped (Kiseleva et al., 2010).

Thus, the main goal of our work was to assess the genetic diversity of the main cattle breeds bred in the Russian Federation and Ukraine 
using MS-DNA loci, as well as to evaluate the phylogenetic relationships between them.

\section{Materials and methods}

Materials. An analysis of molecular genetic diversity was carried out in different cattle breeds represented both in the Russian Federation and Ukraine. A total of 752 individuals, which belonged to eight breeds of the dairy and meat productivity directions, were studied (Table 1).

\section{Table 1}

Information on eight Russian and Ukrainian cattle breeds included in the microsatellite marker analysis

\begin{tabular}{lclc}
\hline \multicolumn{1}{c}{ Breed } & $\begin{array}{c}\text { Abbre- } \\
\text { viation }\end{array}$ & \multicolumn{1}{c}{ Origin of the samples } & $\begin{array}{c}\text { Sample } \\
\text { size, } n\end{array}$ \\
\hline Ayrshire & Ayr & Russia, Belgorod region & 100 \\
Black Pied Holstein & BPH & Russia, Belgorod region & 100 \\
Simmental & Sim & Russia, Belgorod region & 100 \\
Brown Swiss & Swiss & Russia, Kaluga region & 21 \\
Russian Red Pied & RP & Russia, Belgorod region & 100 \\
Russian Black Pied & BP & Russia, Belgorod region & 100 \\
Southern Meat & SM & Ukraine, Kherson region & 192 \\
Red Steppe & RS & Ukraine, Mykolayiv region & 39 \\
\hline
\end{tabular}

Ten microsatellite loci recommended by ISAG-FAO and arranged in one multiplex panel (ETH3, INRA023, TGLA227, BM1818, TGLA122, SPS115, TGLA53, BM2113, BM1824 and ETH10) were used as DNA markers.PCR primers were selected taking into account the amplification of all 10 loci in one tube. The size of all amplified PCR products, taking into account all known alleles, was $<300$ base pairs (bp).

The PCR reaction was carried out on a Verity amplifier (Applied Biosystems, USA) in $20 \mu \mathrm{L}$ of a mixture containing $20 \mathrm{ng}$ of genomic DNA, PCR buffer (10 mmol Tris- $\mathrm{HCl}(\mathrm{pH} 8.3), 50 \mathrm{mmol} \mathrm{KCl}, 2 \mathrm{mmol}$ $\left.\mathrm{MgCl}_{2}\right), 0.25 \mathrm{mmol}$ dNTP, $0.5 \mu \mathrm{mol}$ of primer, 1 unit Taq-DNA-polymerase (inhibited for hot start). PCR parameters: $94^{\circ} \mathrm{C}$ for $3 \mathrm{~min} ; 98^{\circ} \mathrm{C}$ for $30 \mathrm{~s} ; 59{ }^{\circ} \mathrm{C}$ for $120 \mathrm{~s}, 4$ cycles; $72{ }^{\circ} \mathrm{C}$ for $90 \mathrm{~s} ; 94^{\circ} \mathrm{C}$ for $30 \mathrm{~s}, 59^{\circ} \mathrm{C}$ for $120 \mathrm{~s}, 6$ cycles; $72^{\circ} \mathrm{C}$ for $90 \mathrm{~s} ; 90^{\circ} \mathrm{C}$ for $30 \mathrm{~s} ; 59^{\circ} \mathrm{C}$ for $120 \mathrm{~s}$, 20 cycles; $72{ }^{\circ} \mathrm{C}$ for $75 \mathrm{~s} ; 68^{\circ} \mathrm{C}$ for $30 \mathrm{~min}$. In this case, the rate of heating from $59^{\circ} \mathrm{C}$ to $72{ }^{\circ} \mathrm{C}$ was not more than $0.3^{\circ} \mathrm{C} / \mathrm{s}$.

Fragment analysis of PCR products was carried out on an ABI PRISM 3500 automated capillary DNA sequencer (Applied Biosystems, USA) using $50 \mathrm{~cm}$ long capillaries and a POP-7 $7^{\mathrm{TM}}$ polymer matrix. The primers were labeled with four fluorescent dyes detected in the channels Blue (FAM), Green (R6G), Yellow (TAMRA), Red (ROX) (Table 2).

Table 2

Characterization of the ISAG recommended microsatellite DNA loci for determining the validation of the origin of cattle

\begin{tabular}{lcc}
\hline \multicolumn{1}{c}{ Locus } & Alleles size range, bp & Dye \\
\hline BM1818 & $248-278$ & R6G \\
BM1824 & $176-197$ & FAM \\
BM2113 & $122-156$ & R6G \\
ETH10 & $206-231$ & ROX \\
ETH3 & $103-133$ & ROX \\
INRA023 & $195-225$ & TAMRA \\
SPS115 & $234-258$ & FAM \\
TGLA122 & $129-184$ & FAM \\
TGLA227 & $75-114$ & FAM \\
TGLA53 & $142-191$ & ROX \\
\hline
\end{tabular}

The SD 450 length standard (Synthol, Russia) was labeled with a fifth, fluorescent dye and was detected in a separate Orange channel simultaneously with PCR products. After amplification, $9 \mu \mathrm{L}$ of $\mathrm{Hi}^{-\mathrm{Di}^{\mathrm{TM}}}$ formamide and $0.5 \mu \mathrm{L}$ of SD 450 size standard solution were added to $1 \mu \mathrm{L}$ of the PCR product. The samples prepared in this way were analyzed on an ABI PRISM 3500 DNA sequencer (Applied Biosystems, USA). Fragments size analysis was done using GeneMapper ${ }^{\mathbb{B}}$ Software version 4.1 software (Applied Biosystems, USA).

Statistical analysis methods. To calculate the genotypes and alleles frequencies, the number of alleles $(\mathrm{Na})$, effective number of alleles (Ae), observed (Ho) and expected (He) heterozygosity, as well as the fixation index (Fis) both for individual MS-DNA loci and for each breed as a whole the GenAIEx version 6.5 software was used (Peakall $\&$ Smouse, 2012). To test the null hypothesis of the absence of breedspecific peculiarities with respect the indicators of genetic diversity, the Friedman two-way analysis of variance by ranks test was carried out using the PAST version 2.14 software (Hammer et al., 2001).

GENEPOP version 4.2 software (Rousset, 2008) was used to verify that the distribution of microsatellite markers genotypes corresponds to the Hardy-Weinberg equilibrium (HWE) via Monte Carlo Markov Chain algorithm (MCMC). Evaluations of Wright's F-statistics (Fis, Fit, and Fst) for each MS-DNA locus as well as gene flow (Nm) between cattle breeds were obtained using the GenAIEx version 6.5 software (Peakall \& Smouse, 2012). The significance level (P) of Wright's F-statistics was calculated using a permutation test with 999 permutations.

The analysis of molecular variance (AMOVA) based on the empirical distribution of the genotypes over 10 microsatellite loci with the determination of the significance level of the $\mathrm{F}_{\mathrm{st}}$ values based on the permutation method (999 permutations were used) was carried out using the GenAIEx version 6.5 software (Peakall \& Smouse, 2012).

Two approaches were used to evaluate the degree of genetic similarity: i) assignment test based on the analysis of microsatellite multilocus genotypes (Pritchard et al., 2000) and ii) the pairwise Nei's genetic distance matrix (Nei, 1972) was calculated using the GenAIEx version 6.5 software (Peakall \& Smouse, 2012).

Subsequently, using this matrix, a Neighbor-Joining (NJ) dendrogram was constructed, as well as the distribution of breed centroids in the space of the first two principal coordinates (PCoA) using the GenAIEx version 6.5 software (Peakall \& Smouse, 2012). An evaluation of the effective population size ( $\mathrm{Ne}$ ) in different cattle breeds was calculated using the NeEstimator version 2.0 software (Do et al., 2014).

\section{Results}

A high level of genetic diversity was noted for all MS-DNA loci included in the analysis. A total of 169 alleles were identified within the 10 loci studied. The largest number (136 alleles) was noted in the Black Pied Holstein, and the smallest number was obtained in the Brown Swiss breed ( 60 alleles). Moreover, the proportion of rare alleles (with a frequency $<0.05$ ) significantly differed among the studied breeds (Pearson Chi-square test: $\left.\chi^{2}=37.54 ; \mathrm{df}=7 ; \mathrm{P}<0.001\right)$. The smallest proportion of rare alleles was noted among cows of the Red Steppe breed (0.219), while for the other breeds it varied in a relatively narrow range (0.417-0.625) (Table 3).

Table 3

Total allelic diversity and the most common alleles (with a frequency $>0.2$ ) in eight Russian and Ukrainian cattle breeds over ten MS-DNA loci (in bp)

\begin{tabular}{lcccccccc}
\hline \multirow{2}{*}{ Locus } & \multicolumn{7}{c}{ Breed } \\
\cline { 2 - 9 } BM1818 & 266 & BPH & Sim & Swiss & RP & BP & SM & RS \\
BM1824 & $180^{*}$ & $188^{*}$ & $188^{*}$ & $196^{*}$ & 184, & 188,190 & 188 & $180,182182,188$ \\
BM2113 & 133 & 135 & 127,133 & 125,129 & 135 & $127,135125,135137,139$ \\
ETH10 & 213 & 217 & 217,219 & 215, & $219 *$ & 219 & 209, & $211,217^{217,219}$ \\
ETH3 & $133^{*}$ & 127 & $121,133^{*}$ & $117^{*}$ & 133 & 125 & 117,121 & 117 \\
INRA023 & 206 & 210 & 210,214, & $208^{*}$ & 216 & $210,214202,214$ & $212^{*}$ \\
SPS115 & $248^{*}$, & 248,252 & $248^{*}$ & 246,252 & $248^{*}$ & $248^{*}$, & 248,250 & $248^{*}$ \\
TGLA122 & 143,161 & 143 & 153 & $147,155151,171$ & 149 & 143 & 141,143 \\
TGLA227 & 89 & 89,91 & 89,93, & $103 *$ & 101 & 89,97 & 77,89 & 81 \\
TGLA53 & 160 & 168 & 176 & $148,156160,162$ & 168 & 156,164 & 160, \\
\hline $\begin{array}{l}\text { Total num- } \\
\text { ber of alleles }\end{array}$ & 103 & 136 & 102 & 60 & 94 & 96 & 104 & 64 \\
$\begin{array}{l}\text { Number of } \\
\text { rare alleles } \\
(<0.05)\end{array}$ & 43 & 85 & 61 & 25 & 43 & 45 & 52 & 14 \\
\hline
\end{tabular}

Note: alleles with a frequency $>0.5$ denoted by asterisks. 
In the context of individual loci, the largest number of alleles for the total sample was noted at the TGLA122 and TGLA53 loci (26 and 25 alleles, respectively), and the smallest number was noted at the ETH10 and SPS1 15 loci (10 alleles).

Some alleles were found with a very high frequency in most of the studied cattle breeds and, thus, they can be considered as species-specific for the species Bos taurus as a whole (Table 3 ). These were alleles 262 and 266 bp (for BM1818), 180 and 188 bp (for BM1824), 125-127 and 133-135 bp (for BM2113), 217-219 bp (for ETH10), 248 and 252 bp (for SPS115). Alleles 117 and 133 bp (for ETH3), 210 and $214 \mathrm{bp}$ (for INRA023), $143 \mathrm{bp}$ (for TGLA122), $89 \mathrm{bp}$ (for TGLA227) and $160 \mathrm{bp}$ (for TGLA53), which prevailed in the 3-4 studied breeds, can also be attributed to them.

For the Brown Swiss breed, the presence of breed-specific alleles was noted, which were found in the sample with a very high frequency (> 0.5): $264 \mathrm{bp}$ (for BM1818), $196 \mathrm{bp}$ (for BM1824), $117 \mathrm{bp}$ (for ETH3), 208 bp (for INRA023) and 103 bp (for TGLA227). Of particular interest are the animals of the Southern Meat breed, which is the result of interspecific hybridization between zebu (B. indicus) and different cattle breeds (B. taurus).

Therefore, in some cases for animals of this breed, a predominance of alleles that are species-specific was noted: alleles of 209-211 bp (for ETH10) and $77 \mathrm{bp}$ (for TGLA227) are markers of B. indicus-ancestors, and $217 \mathrm{bp}$ and $89 \mathrm{bp}$, respectively, markers of B. taurus-ancestors (Kramarenko et al., 2019).

"Private" alleles (i.e. alleles in a single population) were observed for 8 of the 10 studied MS DNA loci (with the exception of BM2113 and ETH10 loci). For different breeds, the number of "private" alleles varied from one to five, which were noted at 1-4 markers (Table 4).

\section{Table 4}

List of "private" alleles in eight Russian and Ukrainian cattle breeds over ten MS-DNA loci (in bp)

\begin{tabular}{|c|c|c|c|c|c|c|c|c|}
\hline \multirow{2}{*}{ Locus } & \multicolumn{8}{|c|}{ Breed } \\
\hline & Ayr & $\mathrm{BPH}$ & Sim & Swiss & $\mathrm{RP}$ & $\mathrm{BP}$ & SM & RS \\
\hline BM1818 & - & $278^{*}$ & - & - & - & - & 272,274 & - \\
\hline BM1824 & - & - & - & $198^{*}$ & - & - & - & - \\
\hline$B M 2113$ & - & - & - & - & - & - & - & - \\
\hline ETH10 & - & - & - & - & - & - & - & - \\
\hline ETH3 & - & - & - & - & $135^{*}$ & 107 & $101 *$ & - \\
\hline INRA023 & $224^{*}$ & - & - & - & - & - & $194 *$ & - \\
\hline SPS115 & - & $242^{*}$ & - & - & - & - & 244 & - \\
\hline$T G L A 122$ & - & $\begin{array}{l}165 \\
185^{*}\end{array}$ & - & 173 & - & - & - & $\begin{array}{c}133^{*}, \\
137,139\end{array}$ \\
\hline TGLA227 & - & $113^{*}$ & - & - & 101,111 & - & - & - \\
\hline TGLA53 & $144^{*}$ & - & 182,190 & - & - & - & - & - \\
\hline Alleles/Loci & $2 / 2$ & $5 / 4$ & $2 / 1$ & $2 / 2$ & $3 / 2$ & $1 / 1$ & $5 / 4$ & $3 / 1$ \\
\hline
\end{tabular}

Note: the smallest or longest alleles denoted by asterisks.

The largest number of "private" alleles was observed in the Black Pied Holstein and Southern Meat breeds ( 5 alleles). The studied breeds did not significantly differ either in the proportion of "private" alleles in the total allelic diversity $\left(\chi^{2}=4.04 ; \mathrm{df}=7 ; \mathrm{P}=0.775\right)$, nor in the proportion of loci for which "private" alleles were observed $\left(\chi^{2}=6.97\right.$; $\mathrm{df}=7 ; \mathrm{P}=$ 0.432). As expected, in half of the cases that we identified (in 11 of 23 ), the "private" alleles were those with the largest and/or smallest length (in bp), that is, located at the edges of their detection area (Table 4).

The number of alleles (Na) varied from three for the TGLA227 and BM1818 loci (the Brown Swiss breed) to 20 for the TGLA122 and TGLA53 loci (the Black Pied Holstein breed). Accordingly, the highest number of alleles on average was observed in the Black Pied Holstein breed (13.6 alleles per locus), while the Red Steppe and Brown Swiss cows were characterized by the lowest allelic diversity ( 6.4 and 6.0 alleles per locus, respectively) (Table 5).

It is interesting to note that the Brown Swiss cows were characterized by both the smallest effective allele number (Ae) - 1.21 (for TGLA227) and the largest one -9.28 alleles (for BM2113) per locus. On average, the number of effective alleles was the largest in the Black Pied Holstein and Ayrshire breeds (5.6 and 5.2 alleles per locus, respectively), while the smallest value was observed in the Red Steppe and
Brown Swiss breeds (3.8 and 3.3 alleles per locus, respectively) (Table 5). For a single locus, the observed heterozygosity $(\mathrm{Ho})$ varied within very wide limits from 0 (INRA023, the Red Steppe) to 1 (TGLA227, the Ayrshire). In general, the level of observed heterozygosity was quite high; only in 9 cases (out of 80 locus-breed combinations) was it lower than 0.500 . Moreover, in 22 cases, it exceeded the estimate of 0.900 . The average estimates of the observed heterozygosity per locus ranged from 0.603 (the Red Steppe) to 0.870 (the Ayrshire) (Table 5). Again, with respect to the expected heterozygosity (He), the Brown Swiss cows were characterized by both the lowest value ( 0.176 for TGLA227) and the highest one ( 0.892 for BM2113). For animals of the same breed, the lower value of the expected heterozygosity on average per locus $(0.597 \pm 0.067)$ was observed, while the higher value of this indicator was noted in the Black Pied Holstein breed $(0.800 \pm 0.024)$ (Table 5)

\section{Table 5}

Genetic diversity indicators $(\mathrm{x} \pm \mathrm{SE})$ in eight Russian and Ukrainian cattle breeds over ten MS-DNA loci (on average per locus)

\begin{tabular}{lccccc}
\hline Breed & $N a$ & Ae & Ho & He & Fis \\
Ayr & $10.3 \pm 1.2$ & $5.2 \pm 0.6$ & $0.870 \pm 0.046$ & $0.775 \pm 0.034$ & $-0.120 \pm 0.030$ \\
BPH & $13.6 \pm 1.3$ & $5.6 \pm 0.6$ & $0.823 \pm 0.037$ & $0.800 \pm 0.024$ & $-0.033 \pm 0.044$ \\
Sim & $10.2 \pm 1.3$ & $4.0 \pm 0.5$ & $0.808 \pm 0.059$ & $0.698 \pm 0.051$ & $-0.161 \pm 0.033$ \\
Swiss & $6.0 \pm 1.0$ & $3.3 \pm 0.7$ & $0.619 \pm 0.074$ & $0.597 \pm 0.067$ & $-0.042 \pm 0.062$ \\
RP & $9.4 \pm 0.9$ & $4.5 \pm 0.5$ & $0.824 \pm 0.047$ & $0.745 \pm 0.035$ & $-0.104 \pm 0.024$ \\
BP & $9.6 \pm 1.0$ & $4.8 \pm 0.6$ & $0.794 \pm 0.044$ & $0.735 \pm 0.035$ & $-0.064 \pm 0.056$ \\
SM & $10.4 \pm 0.8$ & $4.7 \pm 0.2$ & $0.673 \pm 0.047$ & $0.780 \pm 0.012$ & $0.138 \pm 0.056$ \\
RS & $6.4 \pm 0.6$ & $3.8 \pm 0.4$ & $0.603 \pm 0.094$ & $0.700 \pm 0.037$ & $0.185 \pm 0.116$ \\
\hline
\end{tabular}

In general, for a single locus, an excess of heterozygotes is observed, which is accompanied by negative values of the fixation index (Fis), that was noted in 53 cases (out of 80 locus-breed combinations). Evaluations of the fixation index ranged from -0.314 (ETH3, the Simmental) to 1.000 (INRA023, the Red Steppe). On average for a single locus, the smallest value of fixation index was observed in the Simmental $(-0.161 \pm 0.033)$, and the highest one in the Red Steppe cows $(0.185 \pm 0.116)$ (Table 5).

We noted the presence of breed-specific peculiarities in relation to the values of all used genetic diversity indicators (the Friedman two-way analysis of variance by ranks test: in all cases $\mathrm{P}<0.001-0.015$ ) (Table 6).

\section{Table 6}

The results of the Friedman two-way analysis of variance by ranks test to assess the combined effect of the Russian and Ukrainian cattle breed and the MS-DNA locus on the genetic diversity indicators

\begin{tabular}{|c|c|c|}
\hline Indicator & $\chi^{2}($ for $d f=7)$ & $P$ \\
\hline $\mathrm{Na}$ & 38.053 & $<0.001$ \\
\hline$A e$ & 17.342 & 0.015 \\
\hline Ho & 22.425 & 0.002 \\
\hline $\mathrm{He}$ & 17.554 & 0.014 \\
\hline Fis & 31.114 & $<0.001$ \\
\hline
\end{tabular}

The MS-DNA loci of the studied cattle breeds differed significantly in relation to the Hardy-Weinberg equilibrium (HWE).For the Brown Swiss cows only with respect to one locus (BM1824), and for animals of the Red Steppe breed with respect to two loci (INRA023 and TGLA53), a significant deviation from HWE was observed (in all three cases there was heterozygote deficiency) (Table 7).Whereas, for the Ayrshire, Russian Black Pied and Southern Meat breeds, half of the MS-DNA loci were characterized by a significant deviation from HWE. Moreover, heterozygotes excess was observed in the first two breeds, while for the Southern Meat breed, on the contrary, a significant heterozygotes deficiency was noted in all cases (Table 7).

For the ETH3 locus, a significant deviation from HWE was observed in the 5 studied populations (both in relation to a significant excess and deficiency of heterozygotes), while for the TGLA122 locus, on the contrary, only once (for the Russian Red Pied) was a significant deviation from HWE observed (Table 7). Using evaluations from Wright's F-statistics, we found that the allele and genotype frequencies were significantly different in animals of different cattle breeds (Table 8). Moreover, $\mathrm{F}_{\mathrm{st}}$ values, which reflected a measure of genetic interbreed differentiation, ranged from 0.087 (BM2113) to 0.199 (BM1824). In general, 14.0\% $(\mathrm{P}<$ $0.001)$ of the variability of the genetic structure of the studied animals was 
determined by their breed affiliation, and the remaining $86.0 \%$ was determined by intrabreed variability.

Table 7

Hardy-Weinberg equilibrium (HWE) verification results for eight Russian and Ukrainian cattle breeds over ten MS-DNA loci

\begin{tabular}{lcccccccc}
\hline \multirow{2}{*}{ Locus } & \multicolumn{8}{c}{ Breed } \\
\cline { 2 - 8 } & Ayr & BPH & Sim & Swiss & RP & BP & SM & RS \\
\hline$B M 1818$ & NS & E & NS & NS & NS & E & NS & NS \\
$B M 1824$ & E & NS & E & D & E & NS & NS & NS \\
$B M 2113$ & NS & NS & E & NS & E & NS & NS & NS \\
$E T H 10$ & E & NS & NS & NS & NS & E & NS & NS \\
$E T H 3$ & E & D & NS & NS & E & D & D & NS \\
INRA023 & E & E & NS & NS & NS & NS & D & D \\
SPS115 & NS & NS & E & NS & NS & E & D & NS \\
$T G L A 122$ & NS & NS & NS & NS & E & NS & NS & NS \\
$T G L A 227$ & E & E & E & NS & NS & NS & D & NS \\
$T G L A 53$ & NS & NS & NS & NS & NS & E & D & D \\
\hline
\end{tabular}

Note: NS - deviation from HWE was not detected; $\mathrm{E}-$ significant $(\mathrm{P}<0.05)$ heterozygotes excess was observed; $\mathrm{D}-$ significant $(\mathrm{P}<0.05)$ heterozygotes deficiency was observed.

Table 8

Values of Wright's F-statistics and gene flow (Nm) in eight Russian and Ukrainian cattle breeds over ten MS-DNA loci

\begin{tabular}{lcccc}
\hline \multicolumn{1}{c}{ Locus } & Fis & Fit & Fst & Nm \\
\hline BM1818 & -0.058 & 0.087 & $0.137^{*}$ & 1.57 \\
BM1824 & -0.013 & 0.188 & $0.199^{*}$ & 1.01 \\
BM2113 & -0.042 & 0.049 & $0.087^{*}$ & 2.62 \\
ETH10 & -0.080 & 0.025 & $0.097^{*}$ & 2.32 \\
ETH3 & 0.040 & 0.206 & $0.172^{*}$ & 1.20 \\
INRA023 & -0.046 & 0.131 & $0.169^{*}$ & 1.23 \\
SPS115 & -0.004 & 0.128 & $0.131^{*}$ & 1.66 \\
TGLA122 & -0.078 & 0.046 & $0.116^{*}$ & 1.91 \\
TGLA227 & -0.085 & 0.102 & $0.173^{*}$ & 1.20 \\
TGLA53 & 0.085 & 0.196 & $0.122^{*}$ & 1.81 \\
\hline \multicolumn{1}{c}{$x \pm S E$} & $-0.028 \pm 0.018$ & $0.116 \pm 0.021$ & $0.140 \pm 0.012$ & $1.53 \pm 0.17$ \\
\hline
\end{tabular}

Note: $* \mathrm{~F}_{\mathrm{st}}$ values significantly different from zero $(\mathrm{P}<0.001)$ denoted by asterisks.

Pairwise $\mathrm{F}_{\mathrm{st}}$ and Nei's genetic distances between the eight studied cattle breeds based on the frequencies of alleles at ten microsatellite loci are shown in Table 9. Significant differences $(P<0.001)$ were observed between all pairs of the Russian and Ukrainian cattle breeds included in the analysis. The largest differences in genetic structure were noted between the Brown Swiss breed and the rest of the cattle breeds. On the other hand, as expected, the Russian Black Pied and Black Pied Holstein populations were closest in terms of genetic structure (Table 9).

\section{Table 9}

Pairwise $\mathrm{F}_{\mathrm{st}}$ values (under the diagonal) and Nei's genetic distances (above the diagonal) between eight Russian and Ukrainian cattle breeds over ten MS-DNA loci

\begin{tabular}{lcccccccc}
\hline Breed & Ayr & BPH & Sim & Swiss & RP & BP & SM & RS \\
\hline Ayr & - & 0.505 & 0.439 & 1.450 & 0.513 & 0.425 & 0.556 & 0.679 \\
BPH & $0.180^{*}$ & - & 0.405 & 1.322 & 0.433 & 0.168 & 0.641 & 0.514 \\
Sim & $0.223^{*}$ & $0.195^{*}$ & - & 1.471 & 0.416 & 0.342 & 0.765 & 0.669 \\
Swiss & $0.410^{*}$ & $0.363^{*}$ & $0.469^{*}$ & - & 1.427 & 1.499 & 1.109 & 1.571 \\
RP & $0.215^{*}$ & $0.175^{*}$ & $0.226^{*}$ & $0.424^{*}$ & - & 0.271 & 0.645 & 0.610 \\
BP & $0.181^{*}$ & $0.077^{*}$ & $0.189^{*}$ & $0.409^{*}$ & $0.138^{*}$ & - & 0.501 & 0.550 \\
SM & $0.182^{*}$ & $0.184^{*}$ & $0.259^{*}$ & $0.318^{*}$ & $0.212^{*}$ & $0.175^{*}$ & - & 0.576 \\
RS & $0.253^{*}$ & $0.192^{*}$ & $0.297^{*}$ & $0.414^{*}$ & $0.250^{*}$ & $0.223^{*}$ & $0.196^{*}$ & - \\
\hline
\end{tabular}

Note: $*-\mathrm{F}_{\mathrm{st}}$ values significantly different from zero $(\mathrm{P}<0.001)$ denoted byasterisks.

The results of the assignment test, based on the frequency distribution of multilocus genotypes of MS-DNA loci, indicate that all the cattle breeds included in the analysis are characterized by very high genetic uniqueness. The accuracy of assigning the studied individuals to their own population varied within $95-100 \%$ in different cattle breeds (Table 10). The only exceptions are the Black Pied Holstein animals, among which 13 individuals (out of 100) were mistakenly assigned to the Russian Black Pied breed, as might be expected, given their origin.In fact, out of 100 individuals of the Russian Black Pied breed, only one individual was mistakenly assigned to the Black Pied Holstein breed (Table 10).
Table 10

Results of the assignment test between eight

Russian and Ukrainian cattle breeds over ten MS-DNA loci

\begin{tabular}{lccccccccc}
\hline \multirow{2}{*}{$\begin{array}{c}\text { Breed } \\
\text { (actual) }\end{array}$} & \multicolumn{1}{c}{ Ayr } & BPH & Sim & Swiss & RP & BP & SM & RS & $\begin{array}{c}\text { Percentage of } \\
\text { individuals correctly } \\
\text { assigned, \% }\end{array}$ \\
\hline Ayr & 100 & 0 & 0 & 0 & 0 & 0 & 0 & 0 & 100.0 \\
BPH & 0 & 86 & 0 & 0 & 0 & 13 & 0 & 1 & 86.0 \\
Sim & 0 & 0 & 95 & 0 & 5 & 0 & 0 & 0 & 95.0 \\
Swiss & 0 & 0 & 0 & 21 & 0 & 0 & 0 & 0 & 100.0 \\
RP & 0 & 0 & 0 & 0 & 96 & 4 & 0 & 0 & 96.0 \\
BP & 0 & 1 & 0 & 0 & 1 & 98 & 0 & 0 & 98.0 \\
SM & 0 & 0 & 0 & 0 & 0 & 2 & 188 & 2 & 97.9 \\
RS & 0 & 0 & 0 & 0 & 0 & 0 & 1 & 38 & 97.4 \\
\hline
\end{tabular}

The results of interbreed classification using the $\mathrm{NJ}$ dendrogram of similarity, built on the basis of Nei's genetic distance matrix, show that all Russian and Ukrainian cattle breeds included in the analysis form two clusters. Cluster No. 1 contains genetic groups originating from Holstein, and cluster No. 2 contains the remaining breeds (Fig. 1).

More detailed information on interbreed relationships was obtained using PCoA results based on the matrix of pairwise $\mathrm{F}_{\mathrm{st}}$ values (Fig. 2). As can be seen, the animals of the black- or red-pied root (purebred Holstein or breeds bred from them) again turn out to be close to each other and form the "core", which also includes the Ayrshire breed. The four remaining breeds (the Simmental, Brown Swiss, Red Steppe and Southern Meat) are almost equidistant from the "core" with respect to both the 1st and 2nd Principal Coordinate Axes (Fig. 2), which once again confirms their genetic isolation caused by a different selection strategy inbreeding program.

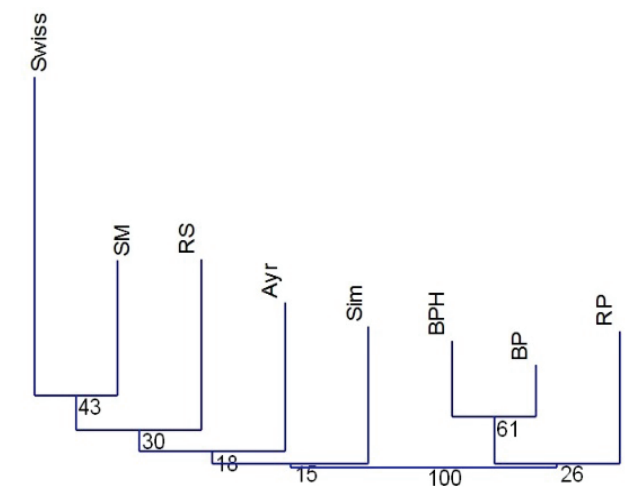

Fig. 1. NJ dendrogram based on the matrix of pairwise Nei's genetic distance between eight Russian and Ukrainian cattle breeds:

Node values $=$ bootstrap test ( 999 pseudoreplicas)

Since different selection strategy in breeding program is very often accompanied by a decrease in intrabreed genetic diversity, the effective population sizes (Ne) of eight Russian and Ukrainian cattle breeds based on the LD method between ten MS-DNA loci were also calculated (Table 11). The results show that three breeds (the Ayrshire, Simmental and Russian Red Pied) are characterized by very low values $(\mathrm{Ne}=33-48)$, which may lead to a loss of their genetic uniqueness in the future.

Two breeds for which estimatesof Ne only slightly exceed the critical value of 50 animals (the Russian Black Pied and Southern Meat) are in danger. Finally, we did not note the threat of loss of genetic diversity for the Black Pied Holstein, Brown Swiss, and Red Steppe breeds, since their Ne estimates exceed 100 animals (taking into account the $95 \%$ confidence interval) (Table 11).

\section{Discussion}

It was found that the highest level of allelic diversity $(\mathrm{Na})$ among the studied cattle breeds was observed for cows of the Black Pied Holstein breed (13.6 alleles per locus). These animals were significantly superior to the Russian Black Pied (Table 5). Earlier, Zinovieva et al. (2015) had already noted that the result of crossbreeding of the Russian Black Pied cattle is a gradual decrease in biodiversity and an increase in its genetic similarity with the Holstein breed. Relatively high $\mathrm{Na}$ values were also 
noted for the Southern Meat (10.4), Ayrshire (10.3), and Simmental (10.2 alleles per locus) breeds. In the first case, the result can be explained by the fact that this breed was obtained as a result of interspecific hybridization between zebu (B. indicus) and different cattle breeds (B. taurus) (Kramarenko et al., 2019). For the Simmental, Na value was significantly higher than for animals of this breed that are bred in Poland-7.7 (Choroszy et al., 2006) or Serbia - 8.8 alleles per locus (Stevanović et al., 2009) and almost two times higher than for the Czech population of the Simmental breed 5.7 alleles per locus (Putnova et al., 2011).

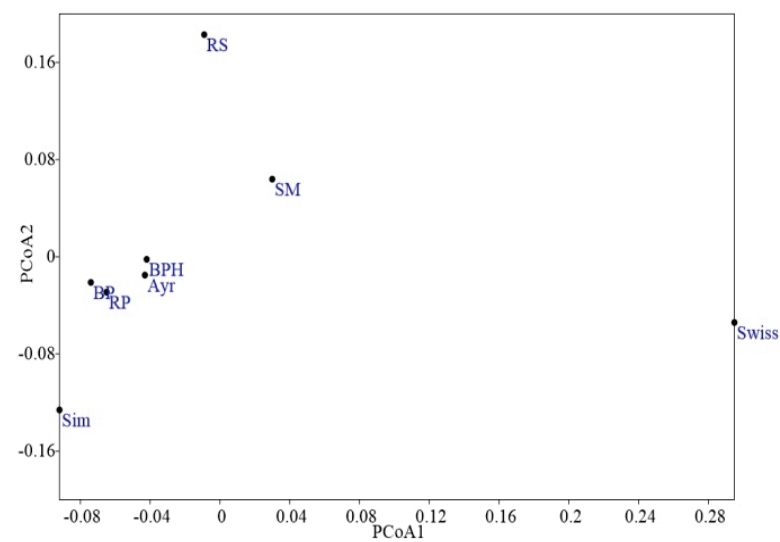

Fig. 2. Principal coordinate analysis (PCoA) of multilocus genotypes of eight Russian and Ukrainian cattle breeds based on the matrix of $\mathrm{F}_{\text {st }}$ pairwise values

Table 11

Estimates of the effective population size $(\mathrm{Ne})$ based on the LD method between ten MS-DNA loci in eight Russian and Ukrainian cattle breeds (individuals)

\begin{tabular}{lcc}
\hline \multicolumn{1}{r}{ Breed } & $\mathrm{Ne}$ & $95 \% \mathrm{CI}$ \\
\hline Ayr & 43.4 & $39-49$ \\
BPH & 105.0 & $90-124$ \\
Sim & 47.9 & $42-55$ \\
Swiss & 57.9 & $27-804$ \\
RP & 33.6 & $30-38$ \\
BP & 62.1 & $54-92$ \\
SM & 64.0 & $57-73$ \\
RS & 77.7 & $45-213$ \\
\hline
\end{tabular}

Note: $95 \%$ CI-95\% confidence interval.

The lowest level of allelic diversity was observed in the Brown Swiss breed (6.0 alleles per locus). This value is significantly lower than previously noted for animals of this breed of the Smolensk type - 7.4 (Gorelov et al., 2011). In the Brown Swiss breed from the original population (Switzerland), this indicator was also higher -6.8 alleles per locus (Schmid et al., 1999). Approximately the same value of $\mathrm{Na}$ was obtained for animals of the Brown Swiss breed, which are bred on farms in Northern Italy - 6.8 alleles per locus (Dalvit et al., 2008).

It was found that high (or low) genetic diversity indicators in different cattle breeds studied were observed for different MS-DNA loci (Table 6), which may indicate the presence of different mechanisms of formation and maintenance of genetic polymorphism in cattle breeds according to the productive directions.It is interesting that among the studied breeds, similar values of the average number of common (with a frequency $>0.05$ ) alleles per locus were observed, while in the average number of rare (with a frequency $<0.05$ ) alleles, on the contrary, the breeds differed significantly from each other (Fig. 3). Thus, the level of allelic diversity for the studied cattle breeds was determined, primarily, by the presence and number of rare alleles (Pearson correlation coefficient: $\mathrm{rP}=0.943$; $\mathrm{df}=6 ; \mathrm{P}<0.001$ ) (Fig. 4).

The estimates of the effective population size $(\mathrm{Ne})$ that we obtained for the studied cattle breeds are generally relatively low (Table 11), which indicates intensive cattle breeding programs with them on farms. These Ne values were significantly lower than the values obtained in other studies. So, for the Ayrshire breed that is bred in South Africa, the Ne value was 148 animals (Maiwashe et al., 2006), which almost three times ex- ceeds our evaluation $(\mathrm{Ne}=43)$. A similar situation was obtained in population of the Simmental breed. Our estimate $(\mathrm{Ne}=48)$ was significantly lower than the evaluations obtained for populations that breed in Ireland $(\mathrm{Ne}=127$; McParland et al., 2007) and Austria ( $\mathrm{Ne}=257$; Sölkner et al., 1998). On the other hand, for the Brown Swiss breed, our estimate $(\mathrm{Ne}=$ 60) turned out to be similar to the value noted for the French population of this breed ( $\mathrm{Ne}=80$; Leroy et al., 2013).

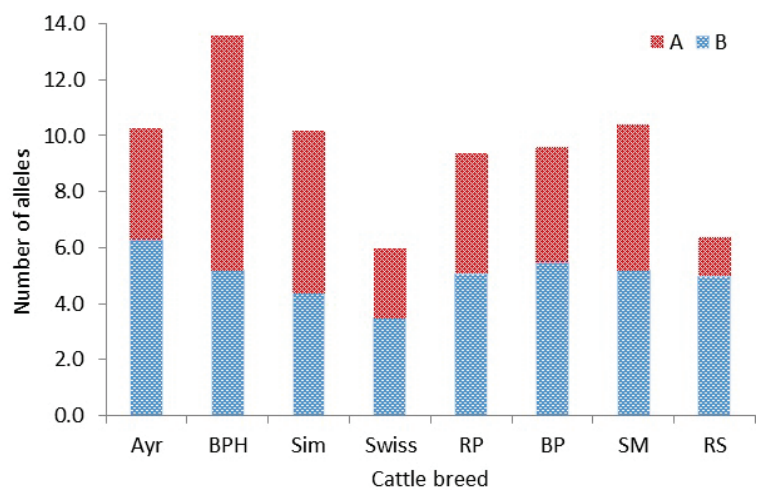

Fig. 3. The average number of rare $(A)$ and common $(B)$ alleles in eight Russian and Ukrainian cattle breeds over ten MS-DNA loci

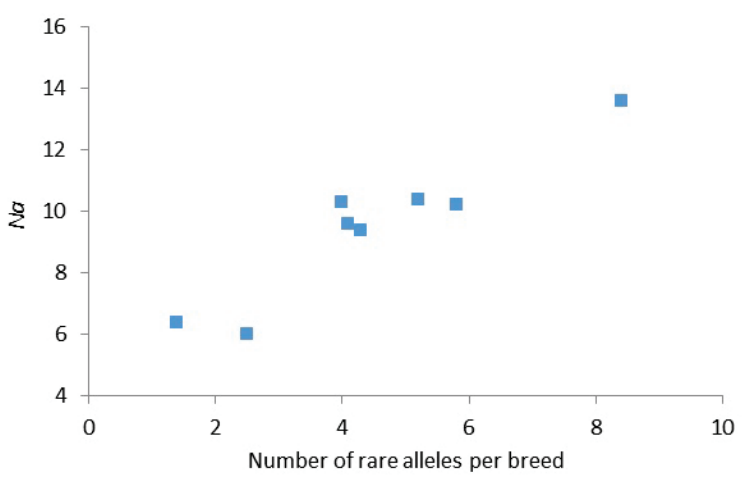

Fig. 4. The relationship between the number of rare alleles and the total allelic diversity (Na) in eight Russian and Ukrainian cattle breeds over ten MS-DNA loci $(\mathrm{rP}=0.943 ; \mathrm{df}=6 ; \mathrm{P}<0.001)$

We also found significant differences between Ne estimates for breeds originated from Holstein, which are bred in Ukraine and the Russian Federation. So, for populations of the Ukrainian Red Pied and Ukrainian Black Pied dairy breeds, Ne values were 555 and 397 animals, respectively (Shelyov et al., 2017), while for populations that are bred in the Russian Federation, these values were 34 and 62 animals, respectively.

Earlier, very low evaluations of $\mathrm{Ne}$, indicating the threatening state of genetic intrabreeding variation, were obtained for the Japanese Black cattle $(\mathrm{Ne}=30$; Nomura et al., 2001), the Mertolenga and Alentejana cattle in Portugal $(\mathrm{Ne}=23-25$; Carolino \& Gama, 2007), and the Wagyu breed in the USA $(\mathrm{Ne}=17$; Scraggs et al., 2014).

\section{Conclusion}

In the study of eight dairy and meat cattle breeds that are bred in the Russian Federation and Ukraine, we found that the breeds differ significantly in the genetic polymorphism indicators over the ten MS-DNA loci used. Moreover, the level of allelic diversity for the studied breeds was determined, primarily, by the presence and number of rare (and/or "private") alleles. This may be due to the manifestation of different mechanisms of the formation and maintenance of genetic polymorphism in breeds, based on productivity direction.

All breeds included in the analysis are characterized by a very high genetic uniqueness based on microsatellite loci; the accuracy of assigning the studied individuals to their own population varied within the range of $95-100 \%$. In general, all breeds studied are grouped into two clusters. Cluster No. 1 contains genetic groups originating from Holstein, and cluster No. 2 contains the remaining breeds. Three breeds (the 
Ayrshire, Simmental and Russian Red Pied) are characterized by very low estimates of the effective population size (less than 50 animals), which may lead to the loss of their genetic uniqueness in the future.

The publication contains the results of studies conducted by President's of Ukraine grant for competitive projects (project number F82/2019) for Dr. A. S. Kramarenko.

\section{References}

Carolino, N., \& Gama, L. T. (2008). Indicators of genetic erosion in an endangerred population: The Alentejana cattle breed in Portugal. Journal of Animal Science, 86(1), 47-56.

Choroszy, B., Janik, A., Choroszy, Z., \& Zabek, T. (2006). Polymorphism of selected microsatellite DNA sequences in Simmental cattle chosen for identification of QTLs for meat traits. Animal Science Papers and Reports, 24(Suppl. 2), 71-77.

Dalvit, C., De Marchi, M., Dal Zotto, R., Zanetti, E., Meuwissen, T., \& Cassandro, M. (2008). Genetic characterization of the Burlina cattle breed using microsatellites markers. Journal of Animal Breeding and Genetics, 125(2), 137-144.

Do, C., Waples, R. S., Peel, D., Macbeth, G. M., Tillett, B. J., \& Ovenden, J. R. (2014). NeEstimator $v 2$ : re-implementation of software for the estimation of contemporary effective population size $(\mathrm{Ne})$ from genetic data. Molecular Ecology Resources, 14(1), 209-214.

Dunin, I., Dankvert, A., \& Kochetkov, A. (2013). Perspektivy razvitiya molochnogo skotovodstva i konkurentosposobnost' molochnogo skota, razvodimogo v Rossiyskoy Federatsii [Prospects for further development of dairy cattle breeding and competitiveness of dairy cattle in the Russian Federation]. Journal of Dairy and Beef Cattle Farming, 3, 1-5 (in Russian).

Gladiy, M. V., Ruban, S. Y., Getya, A. A., \& Pryima, S. V. (2015). Porody sil's'kohospodars'kykh tvaryn Ukrayiny. Istoriya, stan, perspektyvy rozvytku [Breeds of farm animals in Ukraine. History, state, development prospects]. Animal Breeding and Genetics, 49, 44-57 (in Ukrainian).

Gorelov, P. V., Kol'tsov, D. N., Zinovieva, N. A., \& Gladyr', E. A. (2011). Sravnitel'nyy analiz grupp krovi i mikrosatellitov v kharakteristike novykh tipov skota buroy shvitskoy i sychevskoy porod [The comparative analysis of blood groups and microsatellites in characteristics of new cattle types of Swiss and Sychevskaja breeds]. Agricultural Biology, 6, 37-41.

Hammer, Ø., Harper, D. A., \& Ryan, P. D. (2001). PAST: Paleontological statistics software package for education and data analysis. Palaeontologia Electronica, 4(1), 9 .

Kiselyova, T. Y., Podoba, B. Y., Zabludovskiy, Y. Y., Terletskiy, V. P., Vorobyev, N. I., \& Kantanen, J. (2010). Analiz 30 mikrosatellitnykh markerov u shesti lokal'nykh populyatsiy krupnogo rogatogo skota [The analysis of 30 microsatellite markers in six local cattle populations]. Agricultural Biology, 6, 20-25 (in Russian).

Kramarenko, A. S., Karatieieva, O. I., Lykhach, A. V., Lugovoy, S. I., Lykhach, V. Y., Pidpala, T. V., Patryeva, L. S., \& Kramarenko, S. S. (2019). Assessing genomic taurine/zebuine admixture in the southern meat cattle based on microsatellite markers. Ukrainian Journal of Ecology, 9(1), 251-261.
Labinov, V. V., \& Prokhorenko, P. N. (2015). Modernizatsiya cherno-pestroy porody krupnogo rogatogo skota $\mathrm{v}$ Rossii na osnove ispol'zovaniya genofonda golshtinov [Upgrading black-and-white cattle breed in Russia on the basis of the Holstein gene pool]. Dairy and Beef Cattle Farming, 1, 2-7 (in Russian).

Leroy, G., Mary-Huard, T., Verrier, E., Danvy, S., Charvolin, E., \& Danchin-Burge, C. (2013). Methods to estimate effective population size using pedigree data: Examples in dog, sheep, cattle and horse. Genetics Selection Evolution, 45(1), 1.

Maiwashe, A., Nephawe, K. A., van der Westhuizen, R. R., Mostert, B. E., \& Theron, H. E. (2006). Rate of inbreeding and effective population size in four major South African dairy cattle breeds. South African Journal of Animal Science, 36(1), 50-57.

McParland, S., Kearney, J. F., Rath, M., \& Berry, D. P. (2007). Inbreeding trends and pedigree analysis of Irish dairy and beef cattle populations. Journal of Animal Science, 85(2), 322-331.

Nei, M. (1972). Genetic distance between populations. The American Naturalist, 106(949), 283-292.

Nomura, T., Honda, T., \& Mukai, F. (2001). Inbreeding and effective population size of Japanese Black cattle. Journal of Animal Science, 79(2), 366-370.

Peakall, R., \& Smouse, P. E. (2012). GenAIEx 6.5: Genetic analysis in Excel. Population genetic software for teaching and research - An update. Bioinformatics, 28(19), 2537-2539.

Pritchard, J. K., Stephens, M., \& Donnelly, P. (2000). Inference of population structure using multilocus genotype data. Genetics, 155(2), 945-959.

Prokhorenko, P. (2013). Golshtinskaya poroda i ee vliyanie na geneticheskiy progress produktivnosti cherno-pestrogo skota evropeyskikh stran i Rossiyskoy Federatsii [Holstein breed and its influence to genetic progress of black-andwhite cattle performance in European countries and the Russian Federation]. Journal of Dairy and Beef Cattle Farming, 2, 2-6 (in Russian).

Putnova, L., Vrtkova, I., Srubarova, P., \& Stehlik, L. (2011). Utilization of a 17 microsatellites set for bovine traceability in Czech cattle populations. Iranian Journal of Applied Animal Science, 1(1), 31-37.

Rousset, F. (2008). GENEPOP'007: A complete re-implementation of the GENEPOP software for Windows and Linux. Molecular Ecology Resources, 8(1), 103-106.

Scraggs, E., Zanella, R., Wojtowicz, A., Taylor, J. F., Gaskins, C. T., Reeves, J. J., de Avila, J. M., \& Neibergs, H. L. (2014). Estimation of inbreeding and effective population size of full-blood wagyu cattle registered with the American Wagyu Cattle Association. Journal of Animal Breeding and Genetics, 131(1), 3-10.

Shelyov, A. V., Kopylov, K. V., Kramarenko, S. S., \& Kramarenko, O. S. (2017). Analysis of population-genetic processes in different cattle breeds by microsatellite loci of DNA. Agricultural Science and Practice, 4(1), 74-78.

Sölkner, J., Filipcic, L., \& Hampshire, N. (1998). Genetic variability of populations and similarity of subpopulations in Austrian cattle breeds determined by analysis of pedigrees. Animal Science, 67(2), 249-256.

Stevanović, J., Stanimirović, Z., Dimitrijević, V., Stojić, V., Fratrić, N., \& Lazarević, M. (2009). Microsatellite DNA polymorphism and its usefulness for pedigree verification in Simmental cattle from Serbia. Acta Veterinaria, 59(5-6), 621-631.

Zinovieva, N. A., Gladyr, E. A., Bagirov, V. A., \& Brem, G. (2015). Dinamika bioraznoobraziya cherno-pestrogo skota pod vozdeistviem krossbridinga [Dynamics of the biodiversity of black and white cattle influenced by cross-breeding]. Vavilov Journal of Genetics and Breeding, 19(2), 222-225 (in Russian). 